\title{
Penerapan Pendekatan Keterampilan Proses Sains (KPS) dalam Meningkatkan Hasil Belajar Siswa Pada Materi Sistem Ekskresi Manusia Kelas VIII SMP Negeri 2 Tondano
}

\author{
Fatma Bobihu ${ }^{1 *}$, Anneke T. Rondonuwu ${ }^{2}$ \\ 1,2Jurusan Pendidikan IPA, FMIPA, Universitas Negeri Manado \\ *e-mail: fatmabobihu27@gmail.com
}

\begin{abstract}
Abstrak. Penelitian ini ditujukan untuk meningkatkan hasil belajar siswa setelah mengikuti proses pembelajaran dengan menggunakan pendekatan keterampilan proses sains. Penelitian ini dilaksanakan di SMP Negeri 2 Tondano. Metode penelitian yang digunakan adalah Penelitian Tindakan Kelas (PTK) yang dilakukan sebanyak dua siklus, Subjek siswa kelas VIII B yang berjumlah 26 orang siswa. Instrumen yang digunakan adalah lembar observasi keterampilan proses sains dan tes essay. Hasil penelitian dari 26 siswa, pencapaian KKM mengalami peningkatan yaitu rata-rata hasil belajar kognitif siswa pada siklus I sebesar $65,38 \%$ dan mengalami peningkatan pada siklus II menjadi $92,30 \%$ yang tuntas dan hasil belajar keterampilan proses sains siswa pada siklus I $80,76 \%$ dan mengalami peningkatan pada siklus II menjadi $96,15 \%$. Hal ini jelas menunjukan bahwa hasil belajar siswa mengalami peningkatan dari siklus I ke siklus II. Dapat disimpulkan bahwa penerapan pembelajaran dengan pendekatan keterampilan proses sains pada materi sistem ekskresi manusia dapat meningkatkan hasil belajar siswa kelas VIII B SMP Negeri 2 Tondano.
\end{abstract}

Kata kunci: keterampilan proses sains, hasil belajar

\begin{abstract}
This study aims to improve students' learning outcomes after participating in the learning process using the science process skills approach. This research was carried out at the SMP Negeri 2 Tondano. The research method used was Classroom Action Research (PTK), which was carried out in two cycles with the subjects being carried out by Class VIII B students with a total of 26 students. The instruments used were the Science Process Skills Observation Sheet and the Essay Test. The results of the research of 26 students, the performance of KKM has increased, namely the average cognitive learning outcomes of the students in the first cycle of $65.38 \%$ and an increase in the second cycle to $92.30 \%$ which is completed and the learning outcomes of the Science process skills of students in Cycle I $8076 \%$ and an increase from Cycle II to $96.15 \%$. This clearly shows that student learning outcomes have increased from cycle I to cycle II. It can be concluded that applying learning with the scientific process skills approach to the material of the human excretory system can improve the learning outcomes of Class VIII $B$ students of SMP Negeri 2 Tondano.
\end{abstract}

Keywords: scientific process skills, learning outcomes

Diterima 18 Mei 2020 | Disetujui 8 Juni 2020 | Diterbitkan 30 Juni 2020

\section{PENDAHULUAN}

Pendidikan adalah suatu proses yang lebih luas dari pada proses yang berlangsung di dalam sekolah saja. Pendidikan adalah suatu aktivitas sosial yang esensial yang memungkinkan masyarakat yang kompleks. Dalam masyarakat modern, fungsi pendidikan ini mengalami proses spesialisasi dan melembaga dengan pendidikan formal, tetapi masih berhubungan dengan proses pendidikan informal di luar sekolah (Purwanto,2014). 
Pembelajaran IPA hakikatnya merupakan suatu produk, proses, dan aplikasi. Sebagai produk, IPA merupakan sekumpulan pengetahuan dan sekumpulan konsep dan bagan konsep. Sebagai suatu proses, IPA merupakan proses yang dipergunakan untuk mempelajari objek studi, menemukan dan mengembangkan produk-produk Sains, dan sebagai aplikasi, teori teori IPA akan melahirkan teknologi yang dapat memberi kemudahan bagi kehidupan (Trianto,2012).

Berdasarkan pengamatan pada saat praktek pengalaman lapangan (PPL) dan pengamatan pada kelas VIII guru lebih banyak berperan sebagai pengajar yang mentransfer ilmu pengetahuan kepada siswa. Metode pembelajaran yang biasa digunakan adalah metode konvensional. Guru akan membuat soal untuk materimateri yang dirasa penting. Hal ini cenderung membuat siswa kurang aktif dalam proses pembelajaran. Pada saat praktikum di laboratorium sebagian besar siswa menunjukkan keterampilan proses sains yang rendah. Sebagai contoh pada saat melakukan pengamatan/observasi siswa belum mengamati objek dengan cermat. Selain itu siswa kurang teliti dalam melakukan pengukuran menggunakan alat ukur.

Hasil observasi di SMP Negeri 2 Tondano kelas VIII B diperoleh informasi bahwa hasil belajar siswa pada pelajaran IPA masih kurang karena 70\% nilai siswa masih belum mencapai kriteria ketuntasan minimum (KKM) yaitu 75 . Terlihat dari data 26 siswa hanya 8 siswa yang tuntas dalam ujian tengah semester (UTS). Rendahnya nilai rata-rata IPA tersebut disebabkan oleh beberapa faktor diantarannya yaitu masih banyak siswa yang kurang aktif dalam pembelajaran, siswa hanya sebagai pendengar yang pasif, siswa kurang serius dalam menerima materi, mereka tidak memperhatikan apa yang disampaikan guru melainkan hanya menggangu teman sebangku, pembelajaran yang masih berpusat pada guru (teacher center) masih banyak siswa yang belum bisa mengunakan alat-alat laboratorium, dan kurangnya fasilitas sekolah untuk menunjang kegiatan belajar mengajar. Serta guru hanya mengembangakan beberapa keterampilan saja seperti keterampilan berkomunikasi dan keterampilan mengamati.

Pendekatan pembelajaran yang sesuai karakteristik materi pelajaran dapat meningkat hasil belajar siswa. Salah satu pendekatan pembelajaran yang melatih siswa untuk berfikir aktif dalam proses pembelajaran adalah pendekatan keterampilan proses sains. Pembelajaran dengan pendekatan keterampilan proses memungkinkan siswa dapat menumbuhkan sikap ilmiah untuk mengembangkan keterampilanketerampilan yang mendasar, sehingga dalam proses pembelajaran siswa dapat memahami konsep yang dipelajarinya. Dengan demikian hasil belajar yang meliputi pengetahuan, keterampilan, dan sikap sebagai tuntutan kompetensi dalam kurikulum yang dikembangkan saat ini akan tercapai (Subagyo, 2009). Pembelajaran dengan pendekatan keterampilan proses sains memberikan rangsangan kepada siswa berupa pengertian fakta dan konsep ilmu pengetahuan yang lebih baik. Selain itu, siswa diberi kesempatan untuk berinteraksi dengan ilmu pengetahuan, merasakan proses dan produk ilmu pengetahuan dengan aktif (Dimyati \& Mudjiono, 2009).

\section{METODE PENELITIAN}

Penelitian ini telah dilaksanakan pada semester genap tahun ajaran 2019/2020 di SMP Negeri 2 Tondano Kelas VIII B. Pada tanggal 02 Maret 2020 sampai dengan 17 Maret 2020.

Jenis penelitian yang digunakan adalah penelitian tindakan kelas (PTK). Penelitian tindakan kelas merupakan bagian dari penelitian tindakan yang dilakukan oleh guru dan dosen di kelas (sekolah dan perguruan tinggi) tempat mengajar yang bertujuan memperbaiki dan meningkatkan kualitas dan kuantitas proses pembelajaran di kelas. Penelitian tindakan kelas ini dilakukan untuk meningatkan efektifitas metode mengajar, pemberian tugas kepada siswa, penilaian, dan lain sebagainya. Penelitian tindakan 
kelas merupakan jembatan untuk mengatasi berbagai kekurangan penelitian di bidang pendidikan pada umumnya (Azizirrahim, 2015).

Prosedur yang digunakan dalam penelitian ini terdapat beberapa tahap yaitu: Tahap perencanaan, kegiatan yang dilakukan pada tahap ini adalah menyusun perangkat pembelajaran yang akan digunakan yang terdiri dari rencana pembelajaran, lembar observasi sebagai pedoman pemantau sesuai dengan tindakan yang akan digunakan, dan alat evaluasi. Tahap pelaksanaan, pada tahap ini dilaksanakan adalah dengan memberikan masalah sistem ekskresi manusia dan bagaimana cara siswa dalam memecahkan masalah mengenai materi yang diberikan, sesuai dengan metode pembelajaran Pendekatan Keterampilan Proses Sains (KPS) berdasarkan rencana pembelajaran yang dibuat. Pendekatan keterampilan proses sains meliputi observasi, klasifikasi, pengukuran, komunikasi dan kesimpulan. Tahap observasi, pada tahap ini kegiatan yang dilaksanakan adalah mengamati seluruh kegiatan selama tindakan dilaksanakan. Tahap refleksi, Pada setiap akhir pertemuan semua data observasi dan nilai test dianalisis, untuk mengetahui kriteria ketuntasan dan standar presentase yang dicapai siswa. Hasil analisa data digunakan sebagai acuan untuk merencanakan siklus berikutnya. Apabila pada siklus pertama belum mencapai tujuan yang diharapkan maka akan dilanjutkan pada siklus II, dan seterusnya.

Teknik pengumpulan data yang digunakan pada penelitian ini adalah: Observasi, tes tertulis, dokumentasi.

Instrumen pengumpulan data, instrumen pembelajaran: Silabus, rencana pelaksanaan pembelajaran, lembar kerja siswa. Instrumen pengambilan data: lembar observasi keterampilan proses sains, soal tes.

Indikator keberhasilan pada penelitian ini ditandai dengan pencapaian KKM hasil belajar IPA siswa dan observasi keterampilan proses sains sebesar $\geq 85 \%$ sacara klasikal dan $\geq 75$ secara individual.

\section{HASIL DAN PEMBAHASAN Hasil Penelitian}

Data hasil belajar kognitif siswa ditunjukan dengan nilai yang diperoleh siswa setelah mengikuti tes akhir siklus pertama dan kedua yang dapat dilihat pada Tabel 1 dan 2 .

Tabel 1. Analisis ketuntasan hasil belajar siklus pertama

\begin{tabular}{llll}
\hline Nilai & Siswa & Presentase (\%) & Kategori \\
\hline $\mathrm{X}<75$ & 9 & 34.62 & Belum \\
$\mathrm{X} \geq 75$ & 17 & 65.38 & tuntas \\
\hline
\end{tabular}

Tabel 2. Analisis ketuntasan hasil belajar siklus kedua

\begin{tabular}{llll}
\hline Nilai & Siswa & Presentase (\%) & Kategori \\
\hline $\mathrm{X}<75$ & 2 & 7.30 & Belum \\
$\mathrm{X} \geq 75$ & 24 & 92.70 & tuntas \\
\hline
\end{tabular}

Hasil belajar keterampilan proses sains siswa diperoleh dari observasi saat melakukan praktikum. Analisis ketuntasan keterampilan proses sains siswa disajikan pada Tabel 3 dan 4 .

Tabel 3. Analisis ketuntasan KPS siklus pertama

\begin{tabular}{llll}
\hline Nilai & Siswa & Presentase (\%) & Kategori \\
\hline $\mathrm{X}<75$ & 7 & 26.93 & Belum \\
$\mathrm{X} \geq 75$ & 19 & 73.07 & tuntas \\
\hline
\end{tabular}

Tabel 4. Analisis ketuntasan KPS siklus kedua

\begin{tabular}{llll}
\hline Nilai & Siswa & Presentase (\%) & Kategori \\
\hline $\mathrm{X}<75$ & 1 & 3.85 & Belum \\
$\mathrm{X} \geq 75$ & 25 & 96.15 & tuntas \\
\hline
\end{tabular}

\section{Pembahasan}

Penerapan pembelajaran dengan pendekatan keterampilan proses sains meningkatkan rata-rata hasil belajar kognitif siswa tiap siklus diukur dari nilai ujian tengah semester siswa dari 26 orang siswa hanya 8 orang siswa atau $30,76 \%$ yang tuntas dan 18 orang siswa atau $69,24 \%$ belum tuntas. Kemudian tes siklus I diperoleh sebenyak 17 orang siswa atau $65,38 \%$ tuntas dan 9 orang siswa atau $34,62 \%$ belum tuntas yang terdapat pada Tabel 1. Dan pada hasil tes 
siklus II menunjukkan 24 orang siswa atau $92,30 \%$ tuntas dan 2 orang siswa atau $7,70 \%$ yang belum tuntas. Untuk analisis ketuntasan hasil belajar sisklus kedua dapat dilihat pada Tabel 2.

Berdasarkan hasil tersebut dapat dikatakan terjadi peningkatan hasil belajar kognitif siswa sesuai dengan pendapat peneliti sebelumnya bahwa kegiatan laboratorium menjamin keberhasilan siswa dalam proses penemuan ilmiah (Wiyanto, 2008).

Ketuntasan hasil belajar siswa terjadi karena keterlibatan siswa secara langsung dalam proses pembelajaran. Penerapan keterampilan proses sains membuat siswa tidak hanya pasif menerima dan menghafal tetapi berusaha menemukan konsep melalui kegiatan percobaan. Belajar memerlukan keterlibatan pembelajaran secara aktif (Dimyanti \& Mudjiono, 2009).

Penerapan keterampilan proses sains membuat siswa aktif dalam peroses pembelajaran dan siswa terlibat langsung dalam memperoleh konsep sistem Ekskresi melalui pengalaman langsung bukan hanya sekedar mendengar atau menerima konsep sistem Ekskresi dari apa yang disampaikan guru. Belajar yaitu aktifitas mental psikis yang berlangsung dalam interaksi aktif dalam lingkungan yang maknanya adalah pengalaman (Darsono,2000).

Peninggkatan presentase jumlah siswa yang memiliki ketuntasan hasil belajar minimal dari penelitian awal, siklus I dan siklus II. Dengan adanya peningkatan yang terjadi pada siswa yang telah mencapai $92,30 \%$ siswa yang telah tuntas dan indikator keberhasilannya telah tercapai maka dinyatakan bahwa perbaikan pembelajaran ini telah berhasil. Untuk 2 orang siswa yang belum tuntas pada siklus kedua telah dilakukan rimedial dengan soal yang sama. Ketuntasan hasil belajar siswa pada penelitian ini membuktikan bahwa pembelajaran melalui penerapan pendekatan keterampilan proses sains dapat digunakan sebagai salah satu metode untuk meningkatkan pemahaman siswa pada materi pelajaran.
Penilaian keterampilan proses sains diperoleh dari rubrik pengamatan keterampilan proses sains siswa selama pembelajaran berlangsung. Pada penelitian ini, ada beberapa indikator yang diteliti antara lain: Mengobservasi, mengukur, mengkomunikasikan.

Penilaian hasil belajar keterampilan proses sains siswa meliputi 4 indikator. Pertama, mengobservasi atau mengamati terjadi peningkatan dari siklus I ke siklus II. Peningkatan tersebut karena guru sudah menjelaskan terlebih dahulu tentang pengamatan yang akan dilakukan, apa yang akan diamati, dan guru meminta siswa untuk mempelajari LKS terlenih dahulu sehingga siswa lebih tahu apa yng akan dilakukan selama praktikum. Kedua, mengukur terjadi peningkatan dari siklus I ke siklus II, ketepatan siswa dalam pengukuran disebabkan siswa sudah lebih fokus pada kegiatan praktikum dan siswa tidak banyak bermain lagi karena untuk mendapatkan pengukuran yang tepat harus dilakukan dengan serius dan hatihati, serta guru terlebih dahulu menjelaskan cara membaca dan menggunakan alat ukur. Ketiga, menyimpulkan kemampuan menyimpulkan hasil diskusi mengalami peningkatan dari siklus I ke siklus II, hal ini disebabkan karena guru membimbing dan mengarahkan siswa untuk mengambil kesimpulan berdasarkan fakta, konsep, dan prinsip yang diketahui. Keempat, mengkomunikasikan hasil diskusi kelompok masing-masing. Pada saat mempresentasikan hasil diskusi di depan kelas hampir semua siswa telah telah melakukannya dengan baik karena sudah terbiasa melakukan kegiatan diskusi dan tanya jawab. Untuk analisis ketuntasan keterampilan proses sains siswa siklus pertama dan kedua dapat dilihat pada Tabel 3 dan 4 .

Pencapaian nilai keterampilan proses sains siswa dipengaruhi oleh beberapa faktor diantaranya keterlibatan siswa sicara langsung dalam proses pembelajaran, sehingga berakibat pada tingginya nilai keterampilan proses siswa sesuai dengan penelitian yang dilakukan 
oleh peneliti sebelumnya yaitu penggunaan keterampilan proses sangat penting untuk mengukur, menyimpulkan, dan memonitoring tujuan pembelajaran (Rahayu, 2011).

Keterampilan proses sains merupakan bagian penting dalam pembelajaran, karena dengan menggunakan keterampilan proses sains siswa akan lebih mudah paham dengan pelajaran karena siswa terlibat secara langsung pada peroses pembelajaran. Pendekatan keterampilan proses memiliki tujuan agar aktivitas dan kreatifitas peserta didik dalam memperoleh pengetahuan, keterampilan, nilai dan sikap, serta menerapkan dalam kehidupan sehari-hari dan dapat mengembangkan sendiri fakta dan konsep, selain itu menumbuhkan dan mengembangkan sikap dan nilai yang diharapkan (Acesta, 2010).

\section{KESIMPULAN}

Berdasarkan hasil pembahasan penelitian dapat disimpulkan : Penerapan pembelajaran dengan pendekatan keterampilan proses sains pada materi sistem Ekskresi manusia dapat meningkatkan hasil belajar siswa kelas VIII B SMP Negeri 2 Tondano. Hal ini ditunjukkan dengan meningkatnya ratarata hasil belajar kognitif dan keterampilan proses sains siswa.

\section{DAFTAR PUSTAKA}

Acesta, A. (2010). Penerapan Pendekatan Keterampilan Proses Sains untuk Meningkatkan Hasil Belajar Siswa dalam Pembelajaran IPA. Jurnal Pendidikan Dasar, 2(1), 96-106.

Azizirrahim, E. (2015). Penerapan Pendekatan Keterampilan Proses Sains dalam Model Pembelajaran Guided Discovery untuk Meningkatkan Hasil Belajar IPA Fisika pada Siswa Kelas VIIA SMPN 8 Mataram Tahun Ajaran 2015/2016. Jurnal Pendidikan Fisika Dan Teknologi, 1(4), 272-275.

Darsono. (2005). Belajar dan Pembelajaran. Semarang: IKIP Semarang Press.
Dimyati \& Mudjiono. (2009). Belajar dan Pembelajaran. Jakarta: Rineka Cipta.

Purwanto. (2014). Penghantar Pendidikan. Yogyakarta: Graha Ilmu.

Rahayu, E. (2011). Pembelajaran Sains dengan Pendekatan Keterampilan Proses untuk Meningkatkan Hasil Belajar dan Kemampuan Berpikir Kreatif Siswa. Skripsi. Semarang: Jurusan Fisika Fakultas Matematika dan Ilmu Pengetahuan Alam, Universitas Negeri Semarang.

Subagyo. (2009). Pembelajaran dengan Pendekatan Keterampilan Proses Sains untuk Meningkatkan Penguasaan Konsep Suhu dan Pemuaian. Jurnal Pendidikan Fisika Indonesia, 5(2), 4246.

Trianto. (2012). Model Pembelajaran Terpadu. Jakarta: Bumi Aksara.

Widyanto. 2008. Menyiapkan Guru Sains Mengembangka Kompetensi Laboratorium. Semarang: Unnes Press. 